\title{
Ozone Therapy for Remainıng Symptoms after Covid Infection in Male Patients
}

Hayriye Alp

Necmettin Erbakan Universty, Meram Medicine Faculty, GETAT Center, Konya, Turkey.

Corresponding Author: Hayriye Alp, Necmettin Erbakan Universty, Meram Medicine Faculty, GETAT Center, Konya, Turkey.

Received Date: October 16 2021; Accepted Date: October 30, 2021; Published Date: November 13,2021

Citation: Hayriye Alp (2021) Ozone Therapy for Remainıng Symptoms after Covid Infection in Male Patients; J, Clinical Medical Reviews and Reports. 3(9); DOI: 10.31579/2690-8794/104

Copyright: (C) 2021, Hayriye Alp, This is an open access article distributed under the Creative Commons Attribution License, which permits unrestricted use, distribution, and reproduction in any medium, provided the original work is properly cited.

\begin{abstract}
At the end of March, the total number of cases in China, where 3318 people died, is 81.589 . The countries with the highest number of approved cases are America (244 thousand), Italy (115 thousand) and Spain (112 thousand), respectively. In Italy, where the largest number of people died, 13915 people died 15 According to the WHO statement on March 3, 2020, the global fatality rate is 3.4. Determination of seasonal respiratory virus or bacteriological factor in samples taken in the patient according to the possible case definition does not rule out the presence of SARS-CoV2. Patients who received conventional covid treatment in 2021 were included in the study. As exclusion criteria, patients with favism disease and over $100 \mathrm{mg}$ of salicylic acid treatment, and those with ozone and citrus-allergy were excluded from the study. After the informed consent form was signed by the patients, the dose of gamma was increased by 10 in weekly sessions, starting from 10 gamma. major autohomeopathy was applied. The ozone therapy dose was terminated at 40-45 gamma.

Peripheral nodular ground glass densities were found in both lung parenchyma in the computed tomography findings of patients receiving Covid-19 treatment before ozone therapy. It was reported in accordance with high-grade thorax computed tomography findings in terms of coronavirus infection. While the patient's complaints decreased after the 3rd session of major autohomeopathy treatment, it was determined that the symptoms decreased a lot in the 5 th session.

Key words: ozone therapy, covid infection, symptoms
\end{abstract}

\section{Introduction}

At the end of March, the total number of cases in China, where 3318 people died, is 81.589 . The countries with the highest number of approved cases are America (244 thousand), Italy (115 thousand) and Spain (112 thousand), respectively. In Italy, where the largest number of people died, 13915 people died15 According to the WHO statement on March 3, 2020, the global fatality rate is 3.4 [16].

In a case group of 355 patients who died due to COVID-19 in Italy, the underlying chronic disease was emphasized in all of the cases except for 3 . The fact that the population pyramid of our country has a young population ratio is thought to be among the factors that decrease the rate of fatality.

Determination of seasonal respiratory virus or bacteriological factor in samples taken in the patient according to the possible case definition does not rule out the presence of SARS-CoV-2 [17].

The number of breaths with severe pneumomonia> 30 per minute, takiphne, SpO2: saturation <90, those with bad prognostic factors ( $\mathrm{dm}$, kidney kidney failure, ht, immune suppressive, blood lymphocyte count $<800$ micro / 1, crp > 40mg / 1, ferritin500ng / ml, D-dimer > 1000ng / ml) and those with positive radiological findings, hydroxychloracine sulfate and / or azithromycin is added if there is no contraindication to favipiravir. In cases where seasonal influenza cannot be excluded, oseltamivir can be added.

Cases to be followed in intensive care

-»With dyspnea and respiratory distress

-»Respiratory rate $>30$ / min

- $\gg \mathrm{PaO} 2$ / FiO2 $<300$

- »Oxygen demand increased in monitoring

- $\mathrm{SPO} 2<90$ and $\mathrm{PaO} 2<70$ despite $» 5 \mathrm{~L} /$ min oxygen therapy

- »Hypotension (systolic blood pressure $<90 \mathrm{mmhg}$ and more than $40 \mathrm{mmHg}$ drop from usual SKB and mean arterial pressure $<65 \mathrm{mmHg}$, tachycardia $>100 / \mathrm{min}$

- Patients with acute organ dysfunction development and immunosuppression such as acute kidney injury, impairment in acute liver function tests, confusion, acute bleeding diathesis 
-»Troponin height and arrhythmia

-»Lactate $>2$ mmol

- It was determined as the presence of skin disorders such as capillary return disorder and cutis marmaratus [17].

The average hospitalization time of Covid-19 positive patients was determined as 7 days. In those with severe shortness of breath, it can go up to 8 days. It is very important to follow the rules of isolation and disinfection, both at home and in hospital treatment.

The ministry of health has set the criteria for admission to intensive care [17].The average hospitalization time of Covid-19 positive patients was determined as 7 days.

In order not to increase the mortality rates, the intensive care hospitalization rates should be kept as low as possible. If fewer patients are intubated and connected to the intensive care support units, the success rates of coping with the pandemic will increase.

In this study, we tried to examine the patients who had covid infection and received conventional treatment, but whose symptoms did not completely resolve and who received ozone therapy in our polyclinic.

\begin{tabular}{|l|l|l|l|l|l|l|l|l|l|}
\hline Descriptive & AGE & LONG & KG & bmi & sistolik1 & diastolik1 & sistolik2 & diastolik2 & hgb \\
\hline & 16 & 16 & 16 & 15 & 13 & 13 & 13 & 13 \\
\hline N & 1 & 1 & 1 & 2 & 4 & 4 & 4 & 4 & 16 \\
\hline Missing & 44.63 & 1.779 & 102.0 & 32.06 & 115.4 & 72.31 & 109.2 & 71.54 & 16.00 \\
\hline Mean & 45.00 & 1.770 & 97.15 & 30.90 & 110.0 & 70.00 & 110.0 & 70.00 & 16.25 \\
\hline Median & 4.617 & 0.06475 & 19.35 & 4.491 & 9.674 & 5.991 & 10.38 & 5.547 \\
\hline Standard deviation & 35.00 & 1.660 & 76.90 & 27.90 & 110.0 & 70.00 & 100.0 & 70.00 & 14.00 \\
\hline Minimum & 51.00 & 1.870 & 156.0 & 44.80 & 140.0 & 90.00 & 140.0 & 90.00 & 16.80 \\
\hline Maximum &
\end{tabular}

The mechanism of action of ozone doses is explained by the hormeceutical effect. It cannot be explained by pharmacological standards. Absorption, distribution, metabolism and excretion are outside of its pharmacological principles [3, 5]. Ozone dose and biological effects do not show a linear relationship [6].

Ozone therapy is also used in the treatment of covid-19 due to its antiinflammatory, immune modulator, oxygenation, circulatory regulator, oxidant-antioxidant effects. Ozone therapy is used in prophylaxis due to its effects on the immune system and antioxidant system activation. It is used with antiviral effect by making oxidation effects. In the chronic period, it is used in the treatment of fibrosis remaining in the lung tissue.

The antiviral effect of ozone gas is dose-dependent and is due to its oxidant property. Since microorganisms do not have strong antioxidant systems as in healthy cell structure, they can easily be broken down by the oxidant effect of ozone gas. Ozone gas is the third most powerful natural disinfectant in nature after fluorine and persulfate. It is accepted that it provides 3125 times stronger disinfection [1].

The antiviral effect of ozone therapy is due to the oxidation of sulfur groups in the cell membrane [7]. Many viruses can bind to cells thanks to reduced sulfur groups. Ozone can inactivate many virus (norwalk, polio, hepatitis A) groups by binding to reduced sulfur groups(Kekez). 1997, Shin 2003, Herbold 1989, Emerson 1982, Katzenelson, 1979. It has been determined that the HIV-1 virus is prevented from entering the cell by the reduction of membrane disulfide bonds with a similar effect [14].

After administration of O3, blood PO2 levels; It has been shown that it rises from $35 \mathrm{~mm} \mathrm{Hg}$ to $400 \mathrm{~mm} \mathrm{Hg}, \mathrm{O} 2$ dissolves 2-10 times more in the

\section{Discussion}

\section{Method}

Patients who received conventional covid treatment in 2021 were included in the study. As exclusion criteria, patients with favism disease and over $100 \mathrm{mg}$ of salicylic acid treatment, and those with ozone and citrus-allergy were excluded from the study. After the informed consent form was signed by the patients, the dose of gamma was increased by 10 applied. The ozone therapy dose was terminated at 40-45 gamma.

\section{Findıng}

Total 16 patients are included.

Peripheral nodular ground glass densities were found in both lung parenchyma in the computed tomography findings of patients receiving Covid-19 treatment before ozone therapy. It was reported in accordance with high-grade thorax computed tomography findings in terms of coronavirus infection. While the patient's complaints decreased after the 3rd session of major autohomeopathy treatment, it was determined that the symptoms decreased a lot in the 5 th session.

Normal thorax findings were detected in computed tomography scans approximately 6 months later. in weekly sessions, starting from 10 gamma. major autohomeopathy was

\section{Result}

blood, O3, there is a significant increase in arterial blood PO2 pressure, a decrease in $\mathrm{PCO} 2$ pressure and an increase in hemoglobin level, and Hematocrit does not change [11]. With O3 in 12-14 days; Microcirculation improves by $20-60 \%$ in arterial circulation and $10-40 \%$ in venous circulation. Erythrocyte aggregation is improved by $65 \%$ in arterial circulation and $45 \%$ in venous circulation. (Belyaev AN-Russia) O3 Elasticity and deformability of erythrocytes increase, which accelerates microcirculation and increases the release and utilization of oxygen in the capillary area.

O3 improves the function of compensatory collateral anastomoses by increasing the tone of arterioles and facilitating the opening of nonfunctional capillaries. (Magorzata Tafil-Klawela, Alina Woniak, Tomasz Drewa - 2002 / V. Bocci 1996 - 2000 / G. Bojarinov - 1983)

One study reported death after MAH. Gas embolism was reported as the cause of death at autopsy. The reason for this is that while the blood taken from the patient is ozonated, the connection of the blood bottle with the patient is not closed, so the ozone gas given directly enters the circulation. It is seen that the cause of death is not the ozone therapy itself, but an application error [15]. Ozone gas is toxic to living things. Since their antioxidant capacity is very low, the lungs and eyes are the most sensitive organs to the toxic effect of ozone. Sensitivity to ozone varies according to the concentration of the gas in the environment [ppm - part(s) per million], the temperature in the environment, humidity (ozone is more active in a humid environment) and exposure time [9].

\section{Conclusion}

Ozone therapy can be used as a complementary method in patients who have received conventional covid treatment but have prolonged symptoms. 


\section{References}

1. Bocci V. (2006) Scientific and medical aspects of ozone therapy. state of the art. Archives of Medical Research. 37:425-435

2. Bocci V, Valacchi G, Corradeschi F, Fanetti G. (1998) Studies on the biological effects of ozone: 8. Effects on the total antioxidant status and on interleukin-8 production. Mediat Inflamm. 7:313317.

3. Bocci, V.; Borrelli, E.; Travagli, V.; Zanardi, I. (2009) The ozone paradox: Ozone is a strong oxidant as well as a medical drug. Med. Res. Rev. 29, 646-682.

4. Bocci, V.A.; Zanardi, I.; Travagli, V. (2011) Ozone acting on human blood yields a hormetic dose-response relationship. $J$. Transl. Med. 9, 66.

5. Viebahn-Hansler, R.; Leon Fernandez, O.S.; Fahmy, Z. (2012) Ozone in Medicine: The Low-Dose Ozone Concept-Guidelines and Treatment Strategies. Ozone-Sci. Eng. 34, 408-424.

6. Re, L.; Malcangi, G.; Martínez-Sánchez, G. (2012) Medical ozone is now ready for a scientific challenge: Current status and future perspectives. J. Exp. Integr. Med. 2, 193-196.

7. Rowen RJ (2019) Ozone and oxidation therapies as a solution to the emerging crisis in infectious disease management: A review of current knowledge and experience. Med Gas Res 9: 232-237

8. Kekez MM, Sattar SA (1997) A new ozone-based method for virus inactivation: Preliminary study. Phys Med Biol 42: 20272039.
9. Shin GA, Sobsey MD (2003) Reduction of Norwalk virus, poliovirus 1, and bacteriophage MS2 by ozone disinfection of water. Appl Environ Microbiol 69: 3975-3978.

10. Herbold K, Flehmig B, Botzenhart K (1989) Comparison of ozone inactivation, in flowing water, of hepatitis A virus, poliovirus 1, and indicator organisms. Appl Environ Microbiol 55: 2949-2953.

11. Emerson MA, Sproul OJ, Buck CE (1982) Ozone inactivation of cell-associated viruses. Appl Environ Microbiol 43: 603-608.

12. Katzenelson E, Koerner G, Biedermann N, Peleg M, Shuval HI (1979) Measurement of the inactivation kinetics of polio virus by ozone in a fast-flow mixer. Appl Environ Microbiol 37: 715-718.

13. Roy D, Wong PK, Engelbrecht RS, Chian ES (1981) Mechanism of enteroviral inactivation by ozone. Appl Environ Microbiol 41: 718- 723.

14. Ryser H, Levy E, Mandel R, Disciullo G (1994) Inhibition of human immunodeficiency virus infection by agents that interfere with thiol-disulfide interchange upon virus-receptor interaction. Proc Natl Acad Sci USA 91: 4559- 4563.

15. Marchetti D, La Monaca G. (2000) An unexpected death during oxygen-ozone therapy. Am J Forensic Med Pathol. 21(2):144-48.

16. WHO Coronovirus disease.(covid-19) situtation reports 2020.

17. T.C.Sağlık Bakanlığı Halk sağlığı genel müdürlüğü.2020 Covid19 (SarsCov-2 enfeksiyon rehberi-bilim kurulu.erişim tarihi 25.4.2020.
This work is licensed under Creative Commons Attribution 4.0 License

DOI: $10.31579 / 2690-8794 / 104$

Ready to submit your research? Choose Auctores and benefit from:

$>$ fast, convenient online submission

$>$ rigorous peer review by experienced research in your field

$>$ rapid publication on acceptance

$>$ authors retain copyrights

$>$ unique DOI for all articles

$>$ immediate, unrestricted online access

At Auctores, research is always in progress.

Learn more https://auctoresonline.org/journals/clinical-medical-reviews-andreports 